\title{
Effect of antioestrogens on proliferation, differentiation and telomerase activity of pig granulosa cells in vitro*
}

\author{
E. Chronowska ${ }^{1,3}$, M. Tomanek ${ }^{1}$ and T. Kott ${ }^{2}$ \\ Institute of Animal Science, \\ ${ }^{1}$ Department of Biology of Reproduction and \\ ${ }^{2}$ Molecular Genetics \\ Přátelství 815, 10400 Prague Uhř́něves, Czech Republic
}

(Received 6 October 2010; revised version 1 November 2010; accepted 26 November 2010)

\begin{abstract}
The aim of the present work was to study the effect of oestrogen receptor inhibitors (ICI 164.384; ICI and cyclofenil; CF) on proliferation, oestradiol synthesis, aromatase expression and telomerase activity (TA) of pig granulosa cells (GC) derived from small (1-2 mm; SF-GC) and large (5-7 mm; LF-GC) follicles. Cells were treated with anioestrogens for $48 \mathrm{~h}$ in basic (medium only) as well as FSH-stimulated conditions. Antioestrogens applied individually and in a combination significantly $(\mathrm{P}<0.01)$ decreased proliferative potential of LF-GC. Antioestrogens applied in a combination increased $(\mathrm{P}<0.05-0.01) 17-\beta$ oestradiol synthesis in small and large follicle GC. Antioestrogens applied individually and in a combination caused an increase $(\mathrm{P}<0.01)$ of aromatase gene expression in FSH-stimulated conditions as well as in basic conditions. Moreover, antioestrogens increased $(\mathrm{P}<0.05-0.01) \mathrm{TA}$ in basic and in FSH-stimulated conditions. The results of the study indicate the involvement of oestrogen receptor $\alpha$ and $\beta$ in the control of proliferation, differentiation and telomerase activity in pig GC. Furthermore, telomerase activity does not have to be linked only to pig GC proliferation but may also be involved in the differentiation process.
\end{abstract}

KEY WORDS: pig, granulosa cells, oestrogen receptor, antioestrogens, telomerase

\footnotetext{
* Supported by the Agency of Czech Republic, Grant No. 52305 2062, and the Ministry of Agriculture of the Czech Republic, Grant of the MZE 0002701401

${ }^{3}$ Corresponding author: e-mail: chronowska.ewa@gmail.com
} 


\section{INTRODUCTION}

Oestrogens are known to be important factors controlling proliferation and differentiation of granulosa cells (Drummond and Findlay, 1999). Oestrogens exert their role by two subtypes of nuclear receptors: ER $\alpha$ and ER $\beta$. Both subtypes of ER have been localized in mammalian ovary. Tomanek et al. (1997) localized protein as well as mRNA of ER $\alpha$ in the sheep ovary. High amount of ER $\beta$ protein and mRNA was detected in the granulosa cells of primary, secondary and antral follicles in rodents (Tremblay et al., 1997; Sar et al., 1999) and humans (Enmark et al., 1997; Pelletier et al., 2000). On the other hand low amounts of mRNA and protein of ER $\alpha$ (Pelletier et al., 2000; Saunders et al., 2000) were detected in human ovary. Slomczynska and Wozniak (2001) and Slomczynska et al. (2001) localized oestrogen receptor $\alpha$ and $\beta$ in the pig ovary with ER $\beta$ being predominant. ER $\beta$ was present at all stages of follicular development whereas ER $\alpha$ mRNA and protein were detected only in preovulatory follicles and early corpora lutea.

The effect of oestrogens acting through their nuclear receptors on granulosa cell proliferation and follicular growth is still not fully elucidated. Gore-Langton and Daniel (1990) demonstrated an important role of oestrogens in the control of the growth of rat follicles. Antrum formation in vitro in growing preantral follicles was dependent on synergistic action of oestradiol and FSH. It was observed that the proliferative potential of rat granulosa cells in vitro is stimulated by oestradiol and FSH (Bendell and Dorrington, 1991; Bley et al., 1997). Oestradiol applied alone had no effect on the proliferative potential of bovine granulosa cells cultured in vitro (Langhout et al., 1991). On the contrary, the proliferation of pig granulosa cells from small and large follicles decreased as a result of oestradiol stimulation (Ranson et al., 1997). In our previous study (Chronowska et al., 2009), inhibition of oestradiol synthesis with fadrozole resulted in decreased proliferation of pig granulosa cells (GC) from small and large follicles.

In our previous study (Tomanek et al., 2008), we demostrated the presence of telomerase activity in freshly isolated as well as cultured pig granulosa cells obtained from small (1-2) and large (5-7 $\mathrm{mm}$ ) antral follicles. It has been evidenced that telomerase activity is under the control of oestrogens in some oestrogen dependent tissues. Misiti et al. (2000) showed a stimulatory effect of oestrogens on induction of TERT (telomerase reverse transcriptase) expression in human ovarian epithelium. Application of oestradiol to female rats prevented decrease of telomerase activity in granulosa cells (Yamagata et al., 2002). In our previous study (Chronowska et al., 2009), inhibition of oestradiol synthesis by fadrozole resulted in decrease of telomerase activity in pig large follicle granulosa cells. However, the role of oestrogens and the mechanism of their action in telomerase activity regulation in pig granulosa cells is still not fully elucidated. 
Antioestrogens (oestrogen receptor antagonists) are a group of medications that are used in cancer theraphy. They block the effect of oestrogen on the growth of tumor. Antioestrogens work by binding to oestrogen receptors, blocking oestrogen from binding to these receptors. This also blocks oestrogen from activating genes for specific growth-promoting proteins. ICI 164.384, belonging to the group of pure antioestrogens, is $7 \alpha$-alkilamid analog of oestradiol. It blocks ER by the inhibition of AF-1 and AF-2 subdomain activity (Pike et al., 2001). Cyclofenil is non-steroid selective modulator of ER $\beta$. It exhibits 5 times higher affinity to ER $\beta$ than to ER $\alpha$ (Muthyala et al., 2003).

As the effect of oestrogens acting through oestrogen receptors on pig granulosa cell proliferation, differentiation and telomerase activity is still largely unknown, in the present study we applied antioestrogens to elucidate the role of oestrogen receptors in the process of pig granulosa cell proliferation, telomerase activity, oestradiol synthesis and aromatase expression.

\section{MATERIAL AND METHODS}

\section{Isolation of porcine granulosa cells and in vitro culture conditions}

Porcine ovaries were collected from local slaughterhouse and transported to the laboratory in a theromo-cointainer filled with phosphate-buffered saline (PBS) within $30 \mathrm{~min}$. In the laboratory, ovaries were placed in sterile PBS supplemented with an antibiotic antimycotic solution (Sigma, UK) for $20 \mathrm{~min}$ and then cut into small pieces. Individual follicles of desired size (small antral 1-2 $\mathrm{mm}$ and large antral $5-7 \mathrm{~mm}$ ) were isolated from the ovarian pieces by dissection and splitopened under a stereomicroscope (Leica MZ6, Switzerland) into DMEM/F12 medium (Gibco, BRL) to obtain granulosa cells. Cell suspension was treated with trypsin and DNase (Sigma, USA) to eliminate dead cells. The number of living cells in suspension was estimated by use of $0.25 \%$ trypan blue (Sigma, USA) in PBS and by counting in a haematocytometer. Viability of granulosa cells after trypsyn/DNase treatment was $85-90 \%$. Cells were seeded onto 4- or 24well culture microplates Nunclon Delta (Nunc, Denamrk) in a density of 1-1.5 $\mathrm{x} 10^{5}$ of living cells/well and cultured as a proliferating monolayer in a DMEM/ F12 medium supplemented with an insuline-transferrin-selenium mixture (ITS-X, $1 \mathrm{ml} / 100 \mathrm{ml}$ ) and gentamicin (all Gibco, BRL). Two percent of foetal bovine serum (FBS, Gibco) was added in order to facilitate plating. Cell cultures were performed at $37^{\circ} \mathrm{C}$ in a humified atmosphere of $5 \% \mathrm{CO}_{2}$ in a Sanyo MCO-175M incubator. 


\section{Hormonal supplements}

Granulosa cells were cultured for $48 \mathrm{~h}$ in the presence of oestrogen receptor inhibitor ICI 164.384 ( $7 \alpha$ alkilamid analog of oestradiol; Pharma, Cergy, France) supplemented into the culture medium at a concentration of $10^{-7} \mathrm{M}$. Antioestrogens were added to the medium $24 \mathrm{~h}$ after the beginning of the culture. The cyclofenil (ER $\beta$ inhibitor; Sigma, USA) was used at a concentration of $10^{-7} \mathrm{M}$. Testosterone (Steraloids Inc., USA) at a concentration of $10^{-8} \mathrm{M}$ was supplemented as an aromatase substrate. The FSH (pFSH-I-1 Iod/Bio, AFP 10640D, NIADDK$\mathrm{NIH}$, Torrance, CA, USA) was used at a concentration of $50 \mathrm{ng} / \mathrm{ml}$ to induce steroidogenesis in the granulosa cells.

\section{Cell proliferation assay}

To determine the granulosa cell proliferation potential in vitro, the newly synthesized DNA in cell cultures was measured by incorporation of ${ }^{3} \mathrm{H}$-thymidine using the technique of TCA precipitation and liquid scintillation counting as we described earlier (Vackova et al., 2003).

\section{Oestradiol synthesis measurement}

The level of oestradiol synthesis in granulosa cells in vitro was evaluated by radioimmunoassay of oestradiol 17- $\beta$ in the culture medium using RIA techniques which are routinely used in the laboratory (described earlier in Petr et al., 1991). The lower detection limit was $0.066 \mathrm{ng}$ per $\mathrm{ml}$. The intra-assay and inter-assay coefficient of variation was 5.92 and $8.87 \%$, respectively.

\section{Telomerase activity assay}

Preparation of granulosa cells. In vitro cultured granulosa cells were prepared as follows: at the end of in vitro culture, the culture media from individual culture wells were removed and stored at $-20^{\circ} \mathrm{C}$ for RIA. Cells were washed with a serum free medium and PBS and detached by accutase (Chemicon, USA). The cells were then transferred to Eppendorf tubes and centrifuged at $4^{\circ} \mathrm{C}$ and $6000 \mathrm{rpm}$ (3500 G) for $15 \mathrm{~min}$. Pelletes of cells were stored at $-80^{\circ} \mathrm{C}$ until use.

\section{TRAP (Telomeric Repeat Amplification Protocol) assay}

At the time of the telomerase activity assay, cell lysates from in vitro cultured cells were prepared in a CHAPS buffer. Briefly: cell pellets of cultured granulosa 
cells $\left(2 \times 10^{5}\right)$ and the positive control provided in the kit were resuspended with $200 \mu \mathrm{l}$ of $1 \mathrm{X}$ CHAPS Lysis Buffer. The protein concentration was measured spectrophotometrically. A modified protocol based on the TRAPEZE Telomerase Detection Kit (Chemicon, USA) was applied to evaluate telomerase activity. Internal telomerase assay standard and the fluorescent type-specific TS primer AATCCGTCGAGCAGAGTT-6-FAMTM (Applied Biosystems, USA) we used. Telomerase extension and PCR were performed in a Biometra T gradient PCR thermocycler (Biometra, Germany). Telomerase activity was expressed as TPG/ mg protein (Total Product Generated) per milligram of protein.

\section{Real time RT-PCR quantification of the level of P450 aromatase $m R N A$}

Total RNA was isolated from the cultured cells using 6100 Nucleic Acid PrepStation and Total RNA Chemistry (Applied Biosystems (ABI), USA) and quantified by measuring absorbance at $260 \mathrm{~nm}$. Fifty $\mu$ l of RNA was transcribed into cDNA using the cDNA Archive Kit (ABI). Glyceraldehyde 3-phosphate dehydrogenase was used as a reference gene. Aromatase primers (forward, 5'-CTGACCGTCTGTGCCGATT-3'; reverse, 5'GCGGACCTCCT-3') and MGB probe (TET - AATCACCAAGCACCTGGA) and glyceraldehyde 3-phosphate dehydrogenase primers (forward, 5'-GAGCATCTCCTGACTTCCAGTTTC-3'; reverse, 5'CCTAAGCCCCTCCCCTTCT-3') and MGB probe (VIC - ATCCC AGACCCCC) were designed using the Primer Express 3.0 Program (ABI). Quantification of aromatase was performed using the ABI 7500 Fast Real-Time PCR System. The PCR mix composition for one probe was as follows: $1 \mu \mathrm{l}$ of cDNA, $500 \mathrm{nM}$ of forward and reverse primers, $250 \mathrm{nM}$ of TaqMan®MGB probe, $5 \mu \mathrm{l}$ of $1 \mathrm{XTaqMan}{ }^{\circledR F}$ ast Universal MasterMix, NoAmpErase ${ }^{\circledR U N G}$ (Applied Biosystems, USA), water to a volume of $10 \mu \mathrm{l}$. The PCR reaction was continued for 40 cycles after the initial denaturation at $95^{\circ} \mathrm{C}$ for $20 \mathrm{~s}$. Each cycle of PCR consisted of $5 \mathrm{~s}$ of denaturation at $95^{\circ} \mathrm{C}$ and $30 \mathrm{~s}$ of annealing at $60^{\circ} \mathrm{C}$.

\section{Statistical analysis}

The data were obtained from 5 experiments with different pools of smalland large-follicle granulosa cells. Each experiment consisted of three repetitions per treatment. The data are presented as means \pm SEM. All data were analysed using the SAS Programme (SAS 2001, SAS System for Windows, Release 8.2 (TS2M0), SAS Inst. Inc. Cary, NC). Two-way ANOVA was used to determine the significance of differences of ICI 164.384 and cyclofenil effect applied alone and in combination, on proliferation, oestradiol production, aromatase expression and telomerase activity of small-follicle and large-follicle granulosa cells in vitro. Differences with a probability of $\mathrm{P}<0.05$ were considered significant. 


\section{RESULTS}

Granulosa cell proliferation. In FSH-stimulated conditions, antioestrogens applied in a combination decreased $(\mathrm{P}<0.01)$ proliferation rate of small and large GC (Figures 1A and 1B, respectively), while cyclofenil applied alone increased $(\mathrm{P}<0.05)$ proliferation of small follicle granulosa cells (Figure 1A). Antioestrogens applied individually and in a combination significantly $(\mathrm{P}<0.01)$ decreased proliferative potential of LF-GC (Figure 1B).

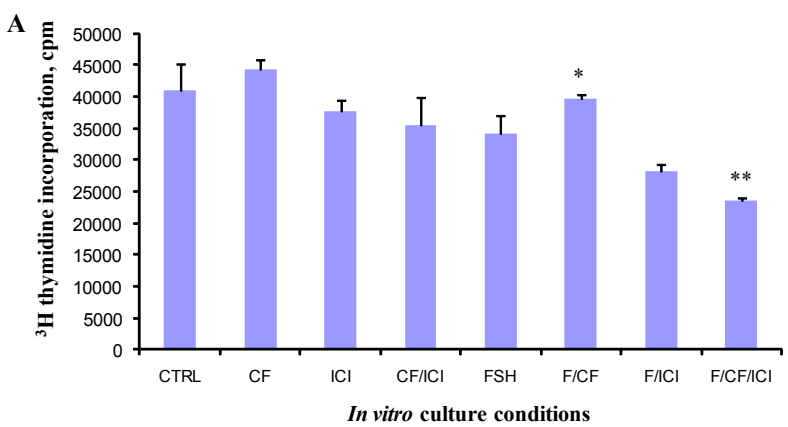

Figure 1A. Proliferation of porcine granulosa cells derived from small (1-2 mm) follicles assayed by incorporation of ${ }^{3} \mathrm{H}$ thymidine after $48 \mathrm{~h}$ of in vitro culture in the presence of ICI 164.384 $\left(10^{-7} \mathrm{M}\right)$ and cyclofenil $\left(10^{-7} \mathrm{M}\right)$ applied individually and in combination in basic conditions and in FSH $(50 \mathrm{ng} / \mathrm{ml})$ stimulated conditions. Each bar represents mean \pm SEM for 5 experiments performed in triplicates. ${ }^{*}$ and $* *$ denotes means significantly different from control (Ctrl for basic conditions, FSH for FSH-stimulated conditions; $\mathrm{P}<0.05-0.01$ )

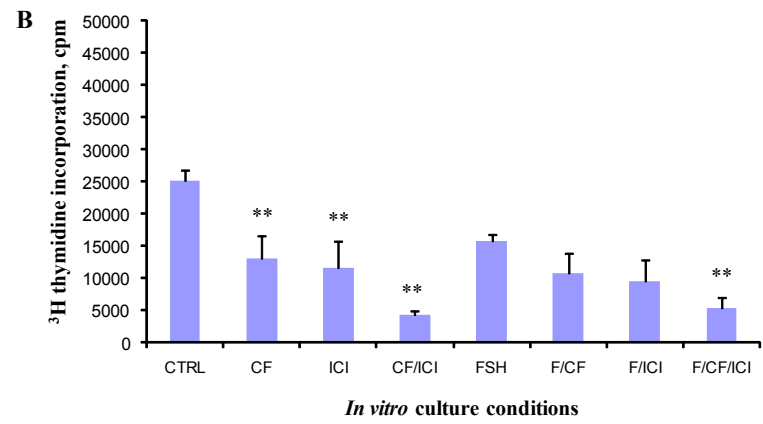

Figure 1B. Proliferation of porcine granulosa cells derived from large $(5-7 \mathrm{~mm})$ follicles assayed by incorporation of ${ }^{3} \mathrm{H}$ thymidine after $48 \mathrm{~h}$ of in vitro culture in the presence of ICI 164.384 $\left(10^{-7} \mathrm{M}\right)$ and cyclofenil $\left(10^{-7} \mathrm{M}\right)$ applied individually and in combination in basic conditions and in $\mathrm{FSH}(50 \mathrm{ng} / \mathrm{ml})$ stimulated conditions. Each bar represents mean $\pm \mathrm{SEM}$ for 5 experiments performed in triplicates. ${ }^{* *}$ denotes means significantly different from control ( $\mathrm{Ctrl}$ for basic conditions, FSH for FSH-stimulated conditions; $\mathrm{P}<0.01$ ) 
Oestradiol synthesis. ICI 164.384 increased $(\mathrm{P}<0.05-0.01)$ oestradiol synthesis in small and large follicle GC in basic as well as FSH-stimulated conditions. Cyclofenil increased $(\mathrm{P}<0.05-0.01)$ oestradiol secretion in small follicle GC. Antioestrogens applied in a combination increased $(\mathrm{P}<0.05-0.01) 17-\beta$ oestradiol (E2) synthesis in small and large follicle GC (Figures 2A and 2B, respectively).

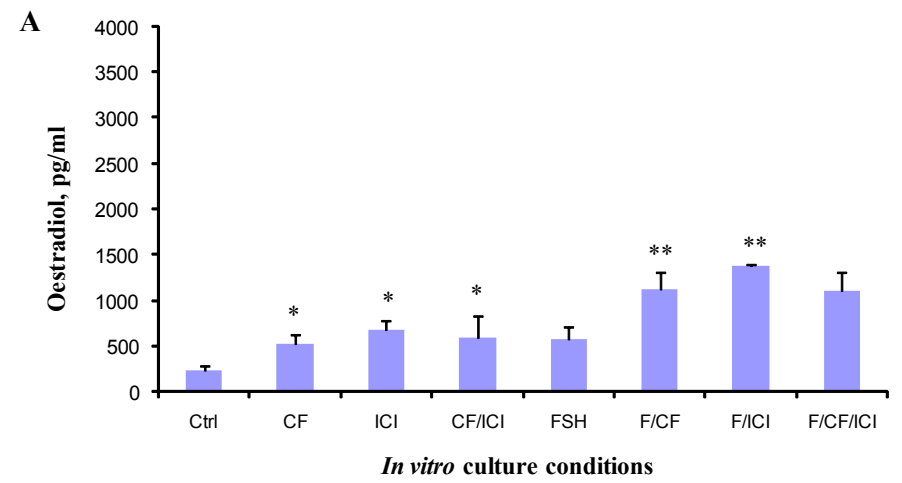

Figure 2A. Oestradiol secretion by porcine granulosa cells derived from small $(1-2 \mathrm{~mm})$ follicles assayed by RIA after $48 \mathrm{~h}$ of in vitro culture in the presence of ICI $164.384\left(10^{-7} \mathrm{M}\right)$ and cyclofenil $\left(10^{-7} \mathrm{M}\right)$ applied individually and in combination in basic conditions and in $\mathrm{FSH}(50 \mathrm{ng} / \mathrm{ml})$ stimulated conditions. Each bar represents mean \pm SEM for 5 experiments performed in triplicates. ${ }^{* *}$ denotes means significantly different from control (Ctrl for basic conditions, FSH for FSH-stimulated conditions; $\mathrm{P}<0.01$ )

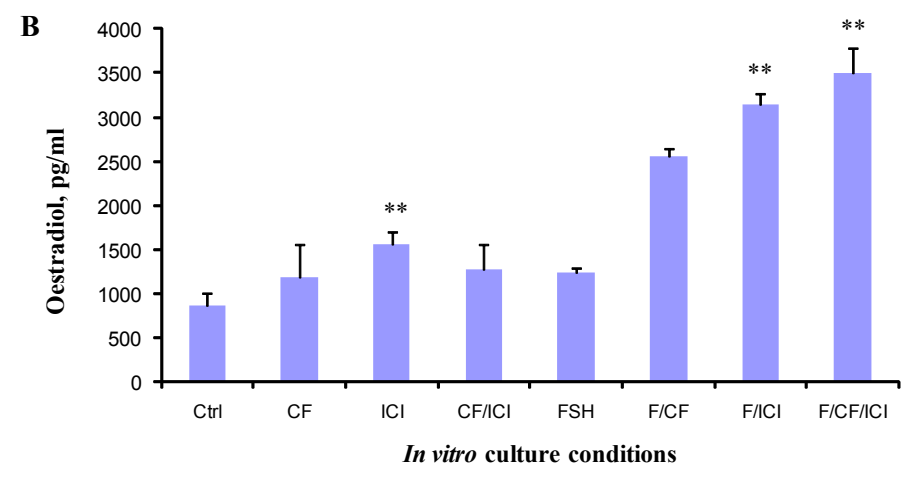

Figure 2B. Oestradiol secretion by porcine granulosa cells derived from large $(5-7 \mathrm{~mm})$ follicles assayed by RIA after $48 \mathrm{~h}$ of in vitro culture in the presence of ICI $164.384\left(10^{-7} \mathrm{M}\right)$ and cyclofenil $\left(10^{-7} \mathrm{M}\right)$ applied individually and in combination in basic conditions and in FSH $(50 \mathrm{ng} / \mathrm{ml})$ stimulated conditions. Each bar represents mean \pm SEM for 5 experiments performed in triplicates. $*$ and $* *$ denotes means significantly different from control (Ctrl for basic conditions, FSH for FSHstimulated conditions; $\mathrm{P}<0.05-0.01)$ 
Aromatase expression. Antioestrogens applied individually and in a combination caused the increase $(\mathrm{P}<0.01)$ in aromatase gene expression in FSH-stimulated conditions [SF-and -LF-GC] and in basic conditions [SF-GC] (Figures $3 \mathrm{~A}$ and $3 \mathrm{~B}$, respectively).

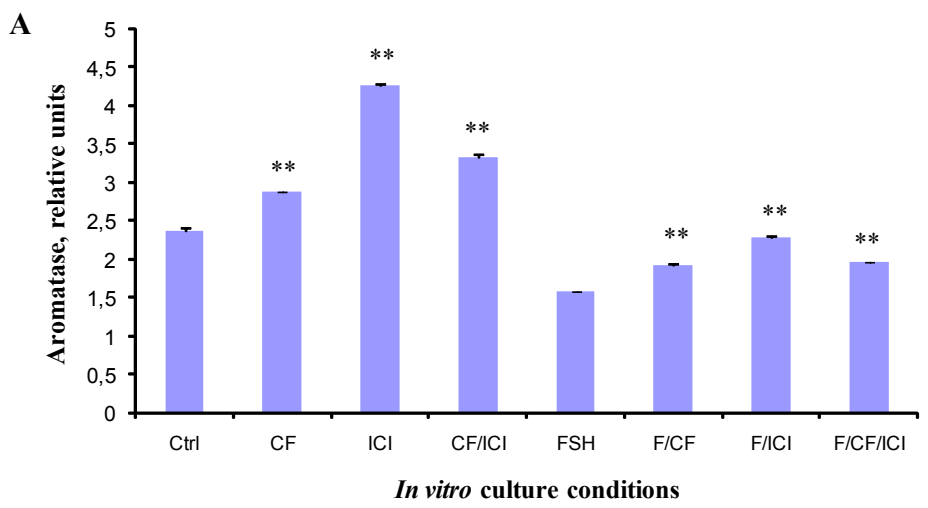

Figure 3A. Aromatase gene expression in porcine granulosa cells derived from small (1-2 mm) follicles assayed by Real Time RT-PCR after $48 \mathrm{~h}$ of in vitro culture in the presence of ICI 164.384 $\left(10^{-7} \mathrm{M}\right)$ and cyclofenil $\left(10^{-7} \mathrm{M}\right)$ applied individually and in combination in basic conditions and in $\mathrm{FSH}(50 \mathrm{ng} / \mathrm{ml})$ stimulated conditions. Each bar represents mean $\pm \mathrm{SEM}$ for 5 experiments performed in triplicates. ${ }^{* *}$ denotes means significantly different from control (Ctrl for basic conditions, FSH for FSH-stimulated conditions; $\mathrm{P}<0.01$ )

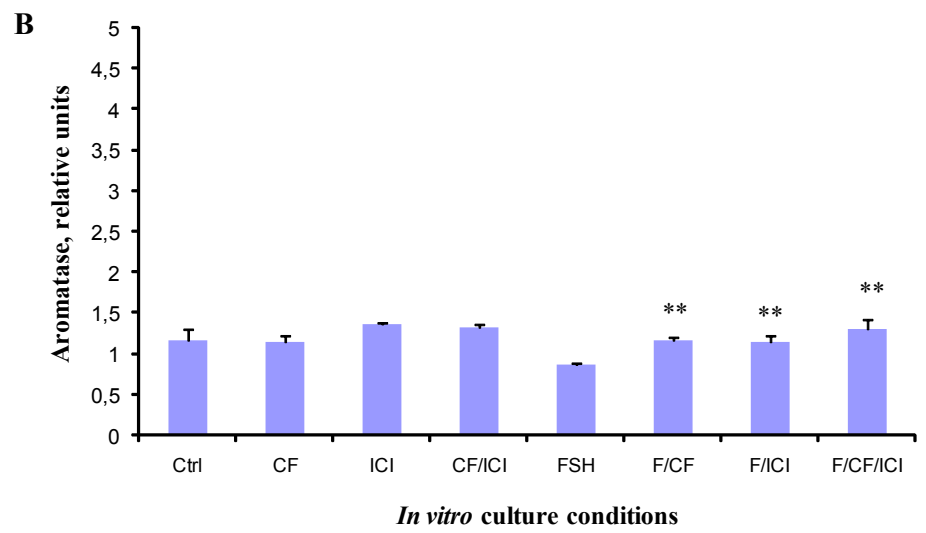

Figure 3B. Aromatase gene expression in porcine granulosa cells derived from large $(5-7 \mathrm{~mm})$ follicles assayed by Real Time RT-PCR after $48 \mathrm{~h}$ of in vitro culture in the presence of ICI 164.384 $\left(10^{-7} \mathrm{M}\right)$ and cyclofenil $\left(10^{-7} \mathrm{M}\right)$ applied individually and in combination in basic conditions and in $\mathrm{FSH}(50 \mathrm{ng} / \mathrm{ml})$ stimulated conditions. Each bar represents mean $\pm \mathrm{SEM}$ for 5 experiments performed in triplicates. ${ }^{* *}$ denotes means significantly different from control ( $\mathrm{Ctrl}$ for basic conditions, FSH for FSH-stimulated conditions; $\mathrm{P}<0.01$ ) 
Telomerase activity. Cyclofenil increased $(\mathrm{P}<0.01)$ telomerase activity in small follicle GC in FSH-stimulated conditions (Figures 4A). ICI 164.384 applied alone increased $(\mathrm{P}<0.05)$ telomerase activity in large follicle $\mathrm{GC}$ in basic as well as FSH-stimulated conditions (Figure 4B). Antioestrogens applied in a combination caused increase $(\mathrm{P}<0.05-0.01)$ in TA in basic conditions [SF-GC] and in FSHstimulated conditions [LF-GC] (Figures $4 \mathrm{~A}$ and 4B, respectively).

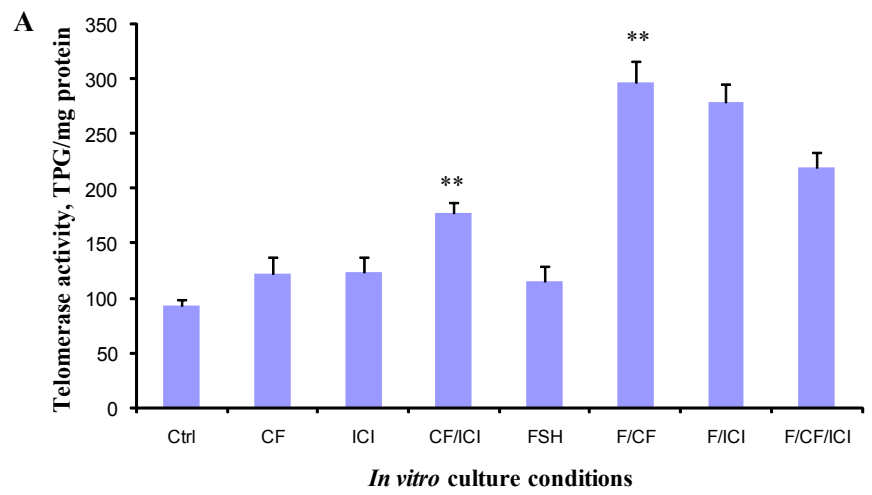

Figure 4A. Telomerase activity in porcine granulosa cells derived from small $(1-2 \mathrm{~mm})$ follicles assayed using TRAPEZE Telomerase ${ }^{\circledR}$ Detection Kit after $48 \mathrm{~h}$ of in vitro culture in the presence of ICI $164.384\left(10^{-7} \mathrm{M}\right)$ and cyclofenil $\left(10^{-7} \mathrm{M}\right)$ applied individually and in combination in basic conditions and in FSH $(50 \mathrm{ng} / \mathrm{ml})$ stimulated conditions. Each bar represents mean \pm SEM for 5 experiments performed in triplicates. $* *$ denotes means significantly different from control (Ctrl for basic conditions, FSH for FSH-stimulated conditions; $\mathrm{P}<0.01$ )

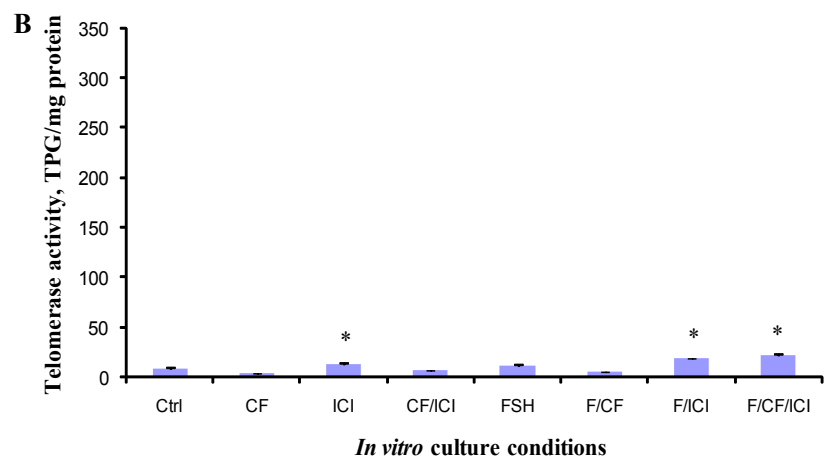

Figure 4B. Telomerase activity in porcine granulosa cells derived from large $(5-7 \mathrm{~mm})$ follicles assayed using TRAPEZE Telomerase ${ }^{\circledR}$ Detection Kit after $48 \mathrm{~h}$ of in vitro culture in the presence of ICI $164.384\left(10^{-7} \mathrm{M}\right)$ and cyclofenil $\left(10^{-7} \mathrm{M}\right)$ applied individually and in combination in basic conditions and in FSH $(50 \mathrm{ng} / \mathrm{ml})$ stimulated conditions. Each bar represents mean \pm SEM for 5 experiments performed in triplicates. * denotes means significantly different from control (Ctrl for basic conditions, FSH for FSH-stimulated conditions; $\mathrm{P}<0.05$ ) 


\section{DISCUSSION}

The generation of the different ER knockout (ERKO) mice provides effective model for studying the physiological consequences of the lack of oestrogen receptor activity (Emmen and Korach, 2003). In the present study, we used antioestrogens to elucidate the role of oestrogens acting through their nuclear receptors on proliferation, differentiation and telomerase activity of pig granulosa cells. The result of the study showed that inhibition of oestrogen receptor by ICI 164.384 and cyclofenil led to decrease of proliferative potential of granulosa cells from small and large follicles. This observation indicates the involvement of both ER subtypes in the stimulation of proliferation of porcine GC derived from small and large follicles. Our results support data obtained from knockout (ER $\alpha \mathrm{KO})$ and $\operatorname{ER} \beta(\mathrm{ER} \beta \mathrm{KO})$ mice. However, even if it is known that oestrogen directly promote follicular growth in mouse it is uncertain which oestrogen receptor is specifically involved. ER $\alpha \mathrm{KO}$ (Rosenfeld et al., 2000) and ER $\beta K O$ (Krege et al., 1998) exhibit follicular development to the Graffian stage. Mice lacking both types of ER were infertile because of follicular arrest (Couse et al., 1999). However, early follicular development in those mice occurred. This observation indicates that oestrogen acting via ER may not be necessary for early stages of follicle development while it is critical for the final stage of folliculogenesis. Involvement of oestrogens acting via ER in the control of granulosa cell proliferation was also observed in cattle. Oestradiol stimulated transition from G1 to S phase of the cell cycle and protected bovine granulosa cells against the apotosis (Quirk et al., 2006).

In other tissues demonstrating the expression of both types of oestrogen receptors, the two receptors seem to counteract each other. In human uterus, immune system and mammary ER $\alpha$ promotes proliferation while ER $\beta$ has proapoptotic and pro-differentiating effects (Morani et al., 2008). Similar results were obtained in quails where high expression of ER $\alpha$ in oviductal tissues was suggested to be related to role of oestrogens in cell proliferation (Hrabia et al., 2004). On the contrary, our results indicate the role for two ER subtypes in the stimulation of proliferation in pig granulosa cells.

In the present study, inhibition of oestrogen receptor with antioestrogens applied individually and in a combination caused the increase in oestradiol production in small and large follicle GC. This indicates the role of both oestrogen receptor subtypes in the control of oestradiol synthesis in pig GC. Similar results were obtained from genetically modified mice. $\mathrm{ER} \alpha \mathrm{KO}$ were characterized by elevated levels of oestradiol in serum. In addition, the lack of ER $\alpha$ was also involved in enhanced synthesis of testosterone and LH (Couse and Korach, 1999). In the present study, inhibition of oestrogen receptor with ICI 164.384 and cyclofenil resulted also in enhanced aromatase expression in granulosa cells. Different 
results were recently obtained in prostate stromal cells where up-regulation of aromatase expression by prostaglandin E2 was mediated by oestrogen receptorrelated receptor $\alpha$ (Miao et al., 2010). These differences may be explained by different regulatory mechanisms in both types of cells.

In the present work, antioestrogens caused an increase in telomerase activity in small and large follicle GC. On the contrary, Misiti et al. (2000) observed that oestrogens induced TERT expression and telomerase activity in human ovarian epithelium cells. In the presence of oestradiol, transient expression of ER $\alpha$ but not ER $\beta$ significantly increased TERT promoter activity. Similar results were obtained in human primary haematopoietic cells where down-regulation of ER $\alpha$ but not ER $\beta$ inhibited oestrogen-stimulated telomerase function (Calado et al., 2009). Oestrogen receptor $\alpha$ was also proved to mediate effect of oestradiol on telomerase activity in human mesenchymal stem cells (Cha et al., 2008).

Interestingly, in the present study we observed that decreased proliferation of GC cultured in the presence of antioestrogens was not accompanied by decreased telomerase activity. On the other hand, elevated oestradiol synthesis caused by antioestrogens action was accompanied by higher telomerase activity. It is widely accepted that level of telomerase activity correlates with proliferative status of the cell (Tanaka et al., 1998). It was not a case in our study, where telomerase activity correlated rather with differentiation status of the cell defined by oestradiol synthesis and aromatase expression. Similar results were earlier obtained in rat. It was shown that telomerase activity in granulosa cells is likely to play significant role for proper follicular development and that the loss of telomerase activity may lead to follicular atresia. The supplementation of oestradiol protected preovulatory follicles from atresia and maintained telomerase activity in the granulosa cells (Yamagata et al., 2002).

\section{CONCLUSIONS}

In conclusion, the results of the present study indicate the involvement of oestrogen receptor $\alpha$ and $\beta$ in the control of proliferation, differentiation and telomerase activity in pig granulosa cells. Moreover, in support of observation of Yamagata et al. (2002), the results of our study indicate that telomerase activity in porcine granulosa cells does not have to be only linked to their proliferation but also may be involved in the control of some differentiation processes. 


\title{
ACKNOWLEDGEMENTS
}

\author{
The authors thank Mrs. Bohumila Krupkova and Mrs. Anna Waldhansova for \\ technical support.
}

\section{REFERENCES}

Bendell J.J., Dorrington J., 1991. Estradiol-17-beta stimulates DNA-synthesis in rat granulosa cells action mediated by transforming growth factor beta. Endocrinology 128, 2663-2665

Bley M.A., Saragueta P.E., Baranao J.L., 1997. Concerted stimulation of rat granulosa cell deoxyribonucleic acid synthesis by sex steroids and follicle-stimulating hormone. J. Steroid Biochem. Mol. Biol. 62, 11-19

Calado R.T., Yewdell W.T., Wilkerson K.L. et al., 2009. Sex hormones, acting on the TERT gene, increase telomerase activity in human primary hematopoietic cells. Blood 114, 2236-2243

Cha Y., Kwon S.J., Seol W., Park K.S., 2008. Estrogen receptor-alpha mediates the effects of estradiol on telomerase activity in human mesenchymal stem cells. Mol. Cell. 26, 454-458

Chronowska E., Tomanek M., Kott T., 2009. Effect of aromatase inhibitor (fadrozole) on proliferation, estradiol production and telomerase activity in pig granulosa cells in vitro. Czech J. Anim. Sci. $54,566-574$

Couse J.F., Curtis-Hewitt S., Bunch D.O. et al., 1999. Postnatal sex reversal of the ovaries in mice lacking estrogen receptor $1 \alpha$ and $\beta$. Science 286, 2328-2331

Couse J.F., Korach K.S., 1999. Estrogen receptor null mice: what have we learned and where they lead us? Endocrine Rev. 20, 358-417

Drummond A.E., Findlay J.K., 1999. The role of estrogen in folliculogenesis. Mol. Cell. Endocrinol. $151,57-64$

Emmen J.M.A., Korach K.S., 2003. Estrogen receptor knockout mice: phenotypes in the female reproductive tract. Gynecol. Endocrinol. 17, 169-176

Enmark E., Pelto-Huikko M., Grandien K. et al., 1997. Human estrogen receptor beta-gene structure, chromosomal localization and expression pattern. J. Clin. Endocrinol. Metab. 82, 4258-4265

Gore-Langton R.E., Daniel S.A., 1990. Follicle-stimulating hormone and estradiol regulate antrumlike reorganization of granulosa cells in rat preantral follicle cultures. Biol. Reprod. 43, 65-72

Hrabia A., Ha Y., Shimada K., 2004. Expression of estrogen receptor alpha mRNA in theca and granulosa layers of the ovary in the relation to follicular growth in quail. Folia Biol. - Krakow 52, 191-195

Krege J.H., Hodgin J.B., Couse J.F. et al., 1998. Generation and reproductive phenotypes of mice lacking estrogen receptor $\beta$. PNAS 95, 15677-15682

Langhout D.J., Spicer L.J., Geisert R.D., 1991. Development of a culture system for bovine granulosa cells effects of growth hormone, estradiol and gonadotropins on cell proliferation, steroidogenesis and protein synthesis. J. Anim. Sci. 69, 3321-3334

Miao L., Shi J., Wang C.Y. et al., 2010. Estrogen receptor-related receptor alpha mediates upregulation of aromatase expression by prostaglandin E2 in prostate stromal cells. Mol. Endocrinol. 24, 1175-1186

Misiti S., Nanni S., Fontemaggi G., 2000. Induction of hTERT Expression and telomerase activity by estrogens in human ovary epithelium cells. Mol. Cell. Biol. 20, 3764-3771

Morani A., Warner M., Gustafsson J.A., 2008. Biological functions and clinical implications of oestrogen receptors alfa and beta in epithelial tissues. J. Intern. Med. 264, 128-142 
Muthyala R.S., Sheng S., Carlson K.E. et al., 2003. Bridged bicyclic cores containing a 1,1diarylethylene motif are high-affinity subtype-selective ligands for the estrogen receptor. J. Med. Chem. 46, 1589-1602

Pelletier G., El-Alfy M., 2000. Immunocytochemical localization of estrogen receptors alpha and beta in the human reproductive organs. J. Clin. Endocrinol. Metab. 85, 4835-4840

Petr J., Tomanek, M., Fulka Jr. J. et al., 1991. Effects of GnRH on preovulatory endocrinology and oocyte maturation in PMSG-superovulated cows. Anim. Reprod. Sci. 24, 37-52

Pike A.C.W., Brzozowski M., Walton J. et al., 2001. Structural insight into the mode of action of a pure antiestrogen. Structure 9, 145-153

Quirk S.M., Cowan R.G., Harman R.M., 2006. The susceptibility of granulosa cells to apoptosis is influenced by oestradiol and the cell cycle. J. Endocrinol. 189, 441-453

Ranson E. J., Picton H. M., Hunter M.G., 1997. Effects of testosterone and oestradiol on [H-3]thymidine incorporation by porcine granulosa and theca cells. Anim. Reprod. Sci. 47, 229-236

Rosenfeld C.S., Murray A.A., Simmer G. et al., 2000. Gonadotropin induction of ovulation and corpus luteum formation in young estrogen receptor- $\alpha$ knockout mice. Biol. Reprod. 62, 599605

Sar M., Welsch F., 1999. Differential expression of estrogen receptor-beta and estrogen receptoralpha in the rat ovary. Endocrinology 140, 963-971

Saunders P.T., Miller M.R., Williams K. et al., 2000. Differential expression of estrogen receptoralpha and beta and androgen receptor in the ovaries of mormostes and humans. Biol. Reprod. 63, 1098-1105

Słomczyńska M., Duda M., Galas J., 2001. Estrogen receptor alpha and beta expression in the porcine ovary. Folia Histochem. Cytobiol. 39, 137-138

Słomczyńska M., Wozniak J., 2001. Differential disrtibution of estrogen receptor-b and estrogen receptor-a in the porcine ovary. Exp. Clin. Endocrinol. Diabetes 109, 238-244

Tanaka M., Kyo S., Takakura M., 1998. Expression of telomerase activity in human endometrium is localized to epithelial glandular cells and regulated in a menstrual phase-dependent manner correlated with cell proliferation. Amer. J. Pathol. 153, 1985-1991

Tomanek M., Chronowska E., Kott T. et al., 2008. Telomerase activity in pig granulosa cells proliferating and differentiating in vitro. Anim. Reprod. Sci. 104, 284-298

Tomanek M., Pisselet C., Monget P., 1997. Estrogen receptor protein and mRNA expression in the ovary of sheep. Mol. Reprod. Dev. 48, 53-62

Tremblay G.B., Tremblay A., Copeland N.G., 1997. Cloning, chromosomal localization and functional analysis of the murine estrogen receptor beta. Mol. Endocrinol. 11, 353-365

Vackova I., Engelova M., Marinov I. et al., 2003. Cell cycle synchronization of porcine granulosa cells in G1 stage with mimosine. Anim. Reprod. Sci. 77, 235-245

Yamagata Y., Nakamura Y., Umayahara K. et al., 2002. Changes in telomerase activity in experimentally induced atretic follicles of immature rats. Endocr. J. 49, 589-595 